\title{
CSR Implementation Concept of Mining Company in Indonesia According to Applicable Law and Theory
}

\author{
M. Rizky Aldila \\ Student at Doctoral Program of Law \\ Universitas Borobudur \\ Jakarta, Indonesia \\ m.rizky.aldila@gmail.com
}

\author{
Faisal Santiago \\ Faculty of Law \\ Universitas Borobudur \\ Jakarta, Indonesia \\ faisalsantiago@borobudur.ac.id
}

\begin{abstract}
Particularly Corporate Social Responsibility (CSR) by Mining Company in Indonesia is regulated in Law Number 40 Year 2007 regarding Limited Liability Company (UUPT ). Howe ver, there are implementation constraints when it turns out that in the CSR arrangements between the articles in the Company Law there is a blurring of norms. if thoroughly observed, CSR arrangements are mandatory as in Article 74 of the Company Law on the background of the government's concern over the frequency of corporations neglecting the social aspects of the environment in the practice of its operations resulting in loss on the part of the local community. Besides also to place state entities in the standards of social activities environment in accordance with national and local contexts. As for the obscurity of norm in article $\mathbf{7 4}$ UUPT can be formulated a legal interpretation through comparative approach (comparative approach) and also theoretical approach (theoretical approach). Various forms of CS R implementation by other countries can serve as a starting point for building the right CSR concept for companies in Indonesia. In general, developed countries in Europe do not formulate the concept of CSR in the form of legislation but with the bottom line theory. The formulation of other forms of CSR activities can also be done as in the guidelines of economic organizations such as the Organization for Economic Cooperation and Development (OECD). The regulation of CS R is mandatory through applicable law provide opportunities for improved conditions of society and the environment at Indonesia. In other words, the proper economic arrangements should be directed to the creation and availability of social benefits that support common interest. By considering other regulations related to CSR, it is necessary to find the best CSR concept to be applied in Indonesia and to give sanction if they violated the law
\end{abstract}

Keywords-CSR Implementation concept of mining company in Indonesia according to applicable law and theory

\section{INTRODUCTION}

The concept of social sustainability emerges as a continuation of the concept of economic sustainability and environmental sustainability that has been triggered before. This concept emerged in a meeting at Yohannesberg in 2002 based on the reasons: 1) the concept of economic sustainability and environmental sustainability developed before it has not been able to lift the welfare of the community in the countries of the world; 2) the need for a set of rules to balance development welfare both in the southem and northern countries. With the background is formulated a common vision in a business world that is more global and leads to liberalization to realize the unity of rules for the welfare of mankind is the concept of social sustainability. In the next development of these three concepts become a benchmark for companies to implement social responsibility that we are familiar with the concept of corporate social responsibility (CSR). CSR is a business commitment to act ethically, operate legally and contribute to improving the quality of life of employees and their families, local communities and the wider community. The concept of CSR involves responsibilities of partnership between the government, the company, and the local community that are active and dynamic[1].

In Indonesia, CSR practices have not become common behavior, because many companies consider as a cost center. However, in the era of information and technology as well as the urgency of globalization, the demands of running a larger CSR. In addition, the implementation of CSR is part of good corporate governance (GCG), namely fairness, transparency, accountability, and responsibility, including responsibility to the physical and social environment, which should be driven through the ethical approach of economic actors. Therefore, in practice, the implementation of CSR is always tailored to the company's capabilities and community needs. Ideally first formulated with the three pillars of the business world, government, and society, and then carried out by the company itself [2]. The company should know in detail the impacts of its operations on all its stakeholders and all relevant government regulations as minimum performance limits, and work as far as possible to pass them on the bas is of ethical norms to be the best.

\section{LITERATURE REVIEW}

\section{A. Coorporate Social Responsibility (CSR)}

Corporate Social Responsibility is a commitment of business actors to have a role and function to the development and empowerment of communities around the business. CSR is a genuine effort of the business entity to minimize negative impacts and maximize the positive impact of the company's operations on all stakeholders in the economic, social and environmental fields to achieve sustainable development goals. 


\section{B. The Limited Liability Company}

The Limited Liability Company hereinafter referred to as the Company, is a legal entity constitutes a capital alliance, established under an agreement, conducting business activities with authorized capital which is entirely divided into shares and meets the requirements as stipulated in this Law and its implementing regulations.

\section{Social and Environmental Responsibility}

Social and Environmental Responsibility is the Company's commitment to participate in sustainable economic development to improve the quality of life and beneficial environment, both for the Company itself, the local community, and society in general.

\section{Triple Bottom Line}

The Triple Bottom Line is a concept that encourages the assessment of overall business performance based on three important areas, that is Profit, People and Planet

\section{E. Sustainable Development}

Sustainable development is the organizing principle for meeting human development goals while at the same time sustaining the ability of natural systems to provide the natural resources and ecosystem services upon which the economy and society depend.

\section{RESEARCH AND METHODS}

The writing of this paper is made with several methods of description analysis, by looking for references to literature [3], which are looking for books related to the material discussed, and searching for knowledge and theories related to the material discussed through the Internet.

\section{RESULT AND DISCUSSION}

\section{A. Coorporate Social Responsibility (CSR) in Indonesia}

Corporate social responsibility (CSR) is an approach where companies integrate social care in their business operations and in their interactions with stakeholders based on the principles of partnership and volunteerism[4]. According to zadek, fostator, rapnas, csr is an inseparable part of the long-term competitive strategy oriented to the avocation of mentoring \& public policy. CSR (Corporate Social Responsibility program) is one of the obligations that must be carried out by the company in accordance with the contents of Article 74 Of Law Number 40 Of 2007 Concerning Limited Company (UUPT)

Article 74 paragraph 1 UUPT stipulates the obligations of the social and environmental responsibility for a company that deals with the field or in relation to natural resources, paragraph 2 concerning the calculation of costs and the principles of decency and fairness, paragraph 3 concerning sanctions, and paragraph 4 concerning the advanced rules. Third, The Law Nomor 25 Year 2007 On Investment. Article 15 (b) states that "every investor shall be obligated to carry out corporate social responsibility". However, this law has only been able to reach foreign investors and has not exp licitly regulated csr for national companies. Of course the two provisions of the above law make phobias a number of people, especially local private business actors. Moreover, the emergence of article 74 of the UUPT which consists of 4 verses had invited polemics. The pros and cons of these provisions still continue today.

Work Concepts and Mechanisms Business is part of the community and has the same social responsibility as the community. In reality, it cannot be denied that the role of the business world has been limited to providing voluntary (philanthropic) financial support and philanthropy so that the activities carried out do not provide real benefits to the community. This raises the dis appointment of the public and the govemment of the lack of role of the business world in social life and the tendency that the implementation of CSR is only to the public's eyes or even in the eyes of their consumers. To overcome this problem, government support is needed as the party responsible for maintaining the survival of the community.

The role of the government in relation to the enterprise is required not as the regulator or controller but rather the party acting as partner[5]. The role of government is needed not only as a policy maker, but also as a facilitator and a dynamicator for the business world in carrying out social responsibility to society. The role of the government as a policy maker will be discussed in more detail in the next discussion. The World Business Council for Sustainable Development defines CSR as the company's commitment to contribute to sustainable economic development, work with company employees, e mployees' families, local co mmunities and the community as a whole in order to improve the quality of life. Sankat and Clement (2002) in Rudito and Famiola (2007) define CSR as a business commitment to act ethically, operate legally and contribute to improving the quality of life of employees and their families, local communities, and the wider commun ity. In general, CSR can be defined as a form of activity to improve the quality of life of the community through the improvement of human capabilities as individuals to adapt to existing social conditions, enjoy, utilize, and maintain the existing environment. CSR is a manifestation of the participation of the business world in sustainable development to develop corporate awareness programs to the surrounding community through the creation and maintenance of a balance between printing profits, social functions, and environmental preservation. In other words, CSR is developed with the Tri Bottom Line corridor which covers social, economic and environmental. A simple example of CSR implementation is to produce products that are safe, not harmful to health, and environmentally friendly; making infiltration wells; distribution of waste properly; and restrictions on the use of air conditioning and electricity.

a) Ernst and Young argues that the company has four main responsibilities: employees, consumers, communities, and the environment. These four things can be a basis for consideration for companies to establish a core program in implementing CSR specifically. There are nine work programs that can be carried out by the company in carrying out CSR activities, that is [1]:

b) Employee Programs Employees are a valuable asset to the company, so it is not surprising if the company is very concerned about the development of employee competency and welfare. Attention to the welfare of employees needs to be expanded not only from the side of health and safety assurance but needs to expand the program such as work life balance program and decision making empowerment program. 
c) Community and Broader Society The majority of companies have activities in this area, one of which is through community empowerment which in essence is how individuals, groups or communities try to control their own lives and strive to shape the future according to their wishes [6]. Implementation of community empowerment through: a. development projects that allow community members to get support in meeting needs. b. campaigns and social actions that allow those needs to be met by other responsible parties.

d) Environtment Programs Programs related to the maintenance of the environment eg by producing products that are safe, harmless to health, and environmentally friendly; making infiltration wells; and waste dis posal well.

e) Reporting and Communications Programs The Company is sues or reports the results of its CSR activities through the annual CSR report so that there is real evidence of corporate participation in carrying out its social responsibilities.

f) Governance or Code of Conduct Programs The company focuses on social activities carried out based on a system regulated by the government. The main thing that must be considered is how stakeholders, government, society, and the business world can make regulations or provisions that are mutually agreed upon to streamline CSR programs. This means that a law is needed to regulate CSR at the macro level such as the target of CSR programs, the standard of program success assessment, and coordination with related parties.

g) Stakeholder Engagement Programs Efforts to create an "effective engagement program" as key to achieving the success of CSR strategy and sustainability strategy.

h) Supplier Programs Establish good relationships based on trust, commitment, sharing of information between the company and its business partners, for example through the management of the supply chain or business network.

i) Customer / Product Stewardship Programs The need for company attention to consumer complaints and guarantee the quality of products produced by the company.

j) Shareholder Programs Program "share value" enhancement for shareholders, because shareholders are a priority for the company. Implementation of CSR should be within the corridor of corporate strategy to achieve the basic objectives of the company's business.

CSR development requires systematic and complex stages. The first stage, begins with the effort to see and assess the needs of the community by identifying the problem and finding the right solution. The second stage, it is necessary to make an action plan along with the budget, schedule, evaluation indicators, and resources needed for the company. The third stage, monitoring activities through direct visits or through surveys. The fourth stage, regular evaluation and reporting to guide the strategy and development of the next program. Evaluation is also done by comparing the results of evaluations from internal companies and external companies. Motivating the Business World to Conduct Corporate Social Responsibility (CSR) Increasing attention to the implementation of CSR marks the era of community awakening so that CSR should not only emphasize the aspect of philantropy (humanitarian drive derived from universal norms and ethics to help others and fight for social equality) and level strategy, but must be further expanded at a more macro and real policy level [4].

To ensure the success of CSR, special experience and knowledge are needed, so companies should be able to learn from the experiences of companies that have implemented CSR programs as one of the company's management policies. Zaidi (2003) in Ambadar (2008) suggests that in its development there has been a paradigm shift in the implementation of corporate social responsibility which includes corporate charity, corporate philanthropy, and corporate citizenship[7]. The first stage, corporate charity is a charity drive based on religious motivation. The second stage is corporate philanthropy, which is a humanitarian drive that usually comes from universal norms and ethics to help others and fight for social equality. The third stage is corporate citizenship, namely citizenship motivation to realize social justice based on the principle of social involvement.CSR is an important issue in ensuring the survival of today's business world. The business world will not be able to develop without regard to the situation and conditions of the social environ ment where the company so that the implementation of CSR becomes a necessity for the company in supporting its business activities, not just the implementation of responsibility but an obligation for the business world.

The implementation of CSR must be a part of the business role and included in the company's business policy, so that the business world is not only an organization that is oriented towards achieving maximum profit but also a learning organization, where every individual involved has a social awareness and a sense of belonging. only in the organizational environment but also in the social environment in which the company is located. CSR is a form of corporate concern for the economy, social, and environment based on three basic principles that include profit, people and the planet (3P). Profit, as a profit oriented business entity, the company must still be oriented to seek economic benefits to ensure the survival of the company so that the company can continue to operate and develop. People, to ensure survival and enhance the competitiveness of enterprises, companies must have concern for the wellbeing of employees and human beings who are valuable assets in organizations and countries. The form of socialoriented CSR programs or people is the provision of scholarships for students around the company, the establishment of educational and health facilities. Planet, environmental awareness and biodiversity sustainability can be done through the implementation of environmental greening program, the provision of clean water facilities, settlement improvement, tourism development.

\section{B. Principles to be Held in Implementing Coorporate Social Responsibility (CSR)}

To support and ensure the achievement of CSR implementation objectives and achieve an effective balance between environment and development requires good governance that involves the government as one of the actors in the regulatory system[8]. Other actors involve individuals in every level of government that are part of civil society. Good governance is defined as a reference to the process and structure of good political and socio-economic relations. In practice, good governance has three interrelated areas of 
focus, namely economics, politics, and admin istration[2] with four principles that must be held, that is:

- The first principle is sustainability or sustainability. This does not mean that the company will continue to provide assistance to the community. However, the designed program must have a sustainable impact. CSR is different from natural and unpredictable natural disaster donations. It is a generosity and good activity;

- The second principle, CSR is a long-term program. Companies must realize that a business can grow because of the support of the social atmosphere of the surrounding environment. Therefore, CSR carried out is a form of maintaining good relations with the community. It is not a momentary activity to boost popularity or pursue profit;

- The third principle, CSR will have a positive impact on society, both economically, environmentally and socially. Companies that do CSR must care and consider until its impact;

- The fourth principle, funds taken for CSR are not included in the cost structure of the company as well as marketing budgets which will eventually be transformed into the selling price of the product. "Correct CSR does not burden consumers;

\section{Indicators of Success in Corporate Social Responsibility (CSR)}

Indicators of success can be seen from two sides of the company and society. From the corporate side, the image should be better in the eyes of the public. Meanwhile, from the community side, there must be an improvement in the quality of life. Therefore, it is important for companies to evaluate to measure the success of CSR programs, both quantitatively and qualitatively. One thing to remember, "One important measure of success of CSR is if the community that is assisted can be independent, not only depends on helping others [8].

\section{CONCLUSION} follows:
Based on the above description, then his conclusion as
Implementation of CSR especially companies engaged in mining and energy should promote effective communication with stakeholders, with attention to the survival of society. It is necessary to imitate some of the successful implementation of CSR in Indonesia, taking into account the quality of life of the community not only in the form of temporary funding assistance but also monitoring and control in order to create sustainability of the CSR program itself. For example the development of food production partners in everyday life, building cooperatives, fostering the community of traditional craftsmen and training and other community empowerment.

\section{REFERENCES}

[1] Law Number 40 Year 2007 About Limited Liability Company

[2] Law Number 25 Year 2007 regarding Investment

[3] Ambadar, J., 2008. Corporate Social Responsibility dalam Praktik di Indonesia. Edisi 1, Penerbit Elex Media Computindo.

[4] Korhonen, J., 2003. On the Ethics of Social Responsibility Considering the Paradigm of Industrial Metabolism, Journal of Business Ethics. 48: 301-315.

[5] Kuncoro, A., 2006. Corruption and Business Uncertainty in Indonesia. Asean Economic Bulletin (April 2006).

[6] Lindgren, D.,2006. CSR Conference Survey. IBL Conference on CSR 2006 in Jakarta. TNS-IBL Survey Report. (2006).

[7] Rees, C, 2006. Conflict Resolution and Prevention through CSR". Presentation Material. Pricewaterhouse Coopers. IBL Conference on CSR. Jakarta.

[8] Rudito, B., Famiola, M., 2007. Etika Bisnis dan Tanggung Jawab Sosial Perusahaan di Indonesia. Edisi 1. Penerbit Rekay asa Bisnis.

[9] Peter Mahmud Marzuki. 2005. Penelitian Hukum. Jakarta: Kencana Prenada Media Group.

[10] Yudha Bhakti Ardhiswastra. 2008. Penafsiran dan Konstruksi Hukum. Bandung: Alumni.

[11] http://www.dipp.depkumham.go.id/hukum-bisnis/84-tanggung-jawabsosial-perusahaan-corporate-social-responsibilit y-dan-iklimpenanaman-modal.html, accessed on Sat urday (28/07/2018)

[12] http://labitacanadase.webs.com/apps/blog/show/2694870 accessed on Sunday $(29 / 07 / 2018)$

[13] http://wiwitna.blogspot.co.id/2013/03/corporate-socialresponsibility.html accessed on Saturday (28/07/2018) https://en.wikipedia.org. accessed on Saturday (28/07/2018) 